\title{
ASSESSMENT OF HEAVY METALS CONTAMINATION IN SURFACE SOILS IN MEIDUK COPPER MINE AREA, SE IRAN
}

\author{
Ali Rezaei ${ }^{*}$, Hossein Hassani ${ }^{1}$, Seyedeh Belgheys Fard Mousavi ${ }^{2}$, Sara Hassani ${ }^{3}$, Nima Jabbari ${ }^{4}$ \\ ${ }^{1}$ Department of Mining and Metallurgy Engineering, Amirkabir University of Technology, Tehran, Iran \\ ${ }^{2}$ Department of Agricultural and Environmental Engineering, Tehran University, Tehran, Iran \\ ${ }^{3}$ Faculty of Life Sciences and Biotechnology, Shahid Beheshti University, Tehran, Iran \\ ${ }^{4}$ Department of Civil and Environmental Engineering, University of Southern California, Los Angeles, USA \\ *Corresponding Author Email: alirezaei2013@aut.ac.ir, hhassani@aut.ac.ir, sb.fardmousavi@alumni.ut.ac.ir, hassanisara85@gmail.com, \\ jabbari@usc.edu
}

This is an open access article distributed under the Creative Commons Attribution License, which permits unrestricted use, distribution, and reproduction in any medium, provided the original work is properly cited.

\section{ARTICLE DETAILS}

\section{Article History:}

Received 15 August 2019 Accepted 17 September 201 Available online 17 October 2019

\section{ABSTRACT}

Mining activities are potentially a significant source of metals contamination in the environment. The purpose of this research is to investigate the environmental impacts of mining activities in the vicinity of Meiduk copper mine. In this study, we use the pollution indices such as contamination factor, enrichment factor and geo-accumulation index for evaluating the metal contaminants, including $\mathrm{Pb}$, Ni, Se, Mo and $\mathrm{Zn}$. The fieldwork consisted of 60 surface soil samples drawn at the depth of $0-30 \mathrm{~cm}$. The samples were, then, analyzed for metals using ICP-MS method. Principal component analysis of compositional data (PCA) was also applied as a multivariate method to find relationships among metals. In the first component (PC1), with $51 \%$ of the total variance, strong and positive loadings related to $\mathrm{Pb}, \mathrm{Se}, \mathrm{Mo}$ and $\mathrm{Zn}$ were evident. The second component (PC2), with $34 \%$ of the total variance, reflected a positive weighting factor of $\mathrm{Ni}$ metal. The obtained results showed that heavy metals levels and distribution were found higher at sites which were in the vicinity of mine pits and waste dumps and were probable sources of metal pollution. As an application of the method proposed in this research, project management will be capable of programming timely and suitable response to these risks by identifying risk factors and their contamination level

\section{KEYWORDS}

Heavy metals, Pollution indices, Multivariate statistical analyses, Meiduk copper mine.

\section{INTRODUCTION}

Soils Heavy metals (HM) contamination has always been one of the challenging global environmental pollution problems. The abundance of contamination sources results in chemical pressures that often manifest as high pollution concentrations or loadings, which in turn show detrimental impacts on human and ecosystem healths [1]. Indirect effects extend over much larger areas, generating a variety of negative impacts on public health and the environment [2]. Soil contamination with heavy metals and metalloids has become an increasingly important issue in recent years. The issue is of outmost importance mainly because of the severe toxicity, broad distribution, persistence, and transferability to ecosystems of these metals compared with other pollutions [3]. Heavy metals such as lead $(\mathrm{Pb})$, zinc $(\mathrm{Zn})$, molybdenum (Mo), selenium (Se) and nickel (Ni) are found naturally in the earth. The mobilization of heavy metals into the biosphere from human activity has become an important process in the geochemical cycling of these metals.

Soils serve as the most important sink for heavy metal contaminants in the terrestrial ecosystem. In recent years, there has been an increasing ecological and global public health concern associated with environmental contamination by these metals. With increasing human and anthropogenic activities, especially mining and industrial processing, these metals have been impacted negatively on the quality of the environment. Mining activities has been identified as a major entry point of heavy metals into the environment and consequently polluting various components of the environment such as soil, water and air [4].
Thus, mining activities are among the main sources of potentially toxic elements (PTEs) in the environment which constitute a real concern worldwide [5]. Extraction of metals from the ores is one of the major source of environmental pollution release and increase of heavy metals through mining [6].

During exploitation, large quantities of wastewater, waste gases and solid wastes are produced by mining activities, which are the main pathways of entry of metals into the surrounding soils. Heavy metals present in tailings of former active mines can also be released to surrounding soils, streams, and groundwater mediated by erosion, weathering, and leaching over a long duration even after the cessation of mining activity [7]. The impact of the mining industry on the environment has been a public concern and has increased awareness of the possible harmful effects of the industry. As an anthropogenic activity, mining has facilitated the movement and distribution of heavy metals in natural formations and anthropogenic activities may change the geochemical distribution of heavy metals more than the lithogenic resources [8,9]. Thus, environmental protection against various pollutants, such as heavy metals formed by industries, mines and modern technologies, is a concern for regulators, researchers as well as different industries.

Many studies have indicated that soils are contaminated by heavy metals and this phenomenon has been attributed mainly to modern industries and mining activities [10]. The origin of environmental pollutions by heavy metals can be categorized in two groups of natural and anthropogenic sources, along with the factors 
affecting their release. Identifying these risk factors and boosting knowledge on the level and type of their effects on the one hand, and proper rating of the pollutant units on the other is essential for correct evaluation and timely and appropriate response to these risks, reducing the loss due to such events in case of their occurrence. Therefore, the study of the concentration, spatial distribution and source identification of heavy metals in soil is very important in order to identify the areas of pollution and assess the potential sources of pollutants [11]. The diversity of pollutants in the soil, along with the need to apply appropriate environmental measures to reduce the risk and irreversible negative consequences on the environment, led to this contaminant evaluation of successful risk management process.

Such mining activities have been carried out for a long time in the Meiduk region. Hence, the main objective of the study was to assess the levels of soil contamination with respect to average concentrations of heavy metals in the region to determine potential linkage between different heavy metals concentrations and their spatial distribution to identify possible sources of contamination that can explain the their spatial patterns in the region. In this study, first, we assessed the risk of pollution from heavy metals through quantitative criteria by applying the multivariate statistical method (principal component analysis) which also helped in evaluation of spatial frequencies and distributions of heavy metals concentration. Then, we calculate selected evaluation criteria, including the enrichment factor (EF), contamination factor (CF), pollution load index (PLI), and geo-accumulation index ( $\left.\mathrm{I}_{\text {geo }}\right)$, to assess the risk of pollution from metals lead, nickel, selenium, zinc and molybdenum. The present study will provide a good basis for further research on the impact of mining and its various processes to the environment.

\section{MATERIALS AND METHODS}

\subsection{The Study Area}

The Meiduk porphyry copper mine is located $135 \mathrm{~km}$ northwest of the Sarcheshmeh in the $45 \mathrm{~km}$ northeast of Shahr-e-Babak as a part of the Urumiyeh-Dokhtar magmatic belt [12]. The location of the Meiduk copper mine is shown in Figure 1. The reason for choosing this area of risk assessment is the presence of local residents and other living organisms that mining activities can pose a threat to.

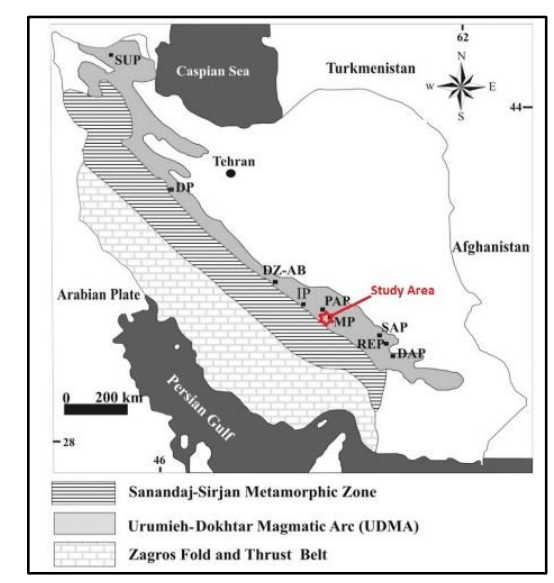

Figure 1: The location of porphyry copper deposits along the UDMA and Geographic location of Meiduk copper mine [12]

\subsection{Sampling strategy and procedures}

Soil samples were collected from 60 selected locations in the vicinity of the Meiduk copper mine area. With a goal of assessing the heavy metals ratio in the surfacial soils of the Meiduk copper mine area, samples were collected from the depth range of $0-30 \mathrm{~cm}$. The soil samples were then transferred to the laboratory, dried, sieved through mesh number 200 and homogenized. Laboratory analysis for $\mathrm{Pb}, \mathrm{Ni}, \mathrm{Se}, \mathrm{Zn}$ and Mo was then performed with the help of Inductively Coupled Plasma-Mass Spectrometer (ICP- MS). Chemical analyses were carried out at the Lab West Laboratories, Australia (www.labwest.net) [13]. Figure 2 shows the location of sampling stations on the geological map.

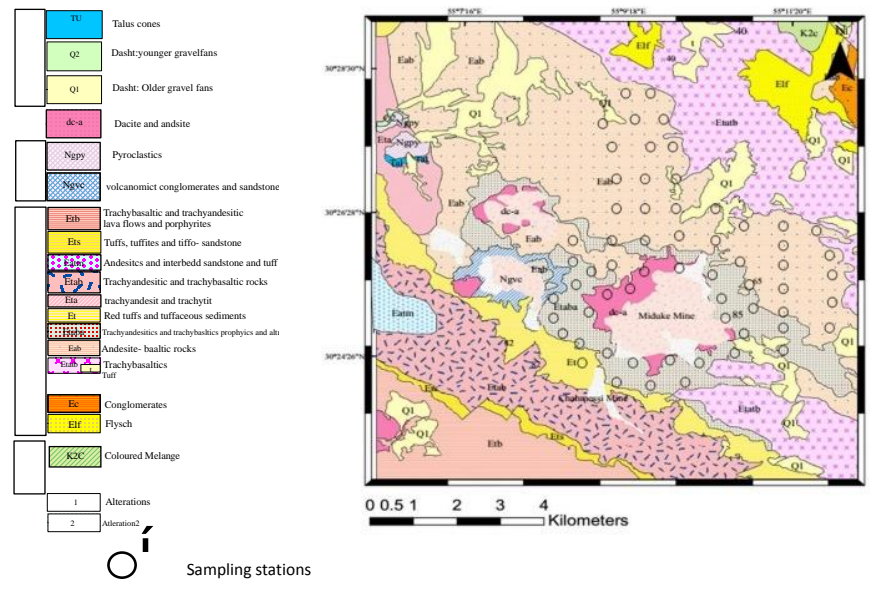

Figure 2: Map of sampling stations of soils in the Meiduk copper mine on geological map (1:50000) [14]

\subsection{Environmental pollution indices}

To determine the extent of mining contamination with heavy metals, the concentrations of chemical elements of a study area are compared with health related values suggested or mandated by international standards. Various methods and factors have been proposed to assess the heavy metal contaminations in a mining district [15]. In this work, soil contamination was assessed using pollution indices such as enrichment factor (EF), contamination factor (CF), contamination degree, pollution load index (PLI), and geo-accumulation index. The following is a review and evaluation of the geochemical and environmental heavy metal contaminations in the regions based on the coefficients. In this study, the above criteria were applied to the soil samples, and were used as indicators for evaluating the pollution risk caused by heavy metals.

\subsubsection{Enrichment Factor (EF)}

The enrichment factor (EF) compares the concentration of an element in samples with the concentration of the same element in the noncontaminated area (i.e. geological background) [8]. The concept of EF was developed in the early 70's to identify the origin of elements in the atmosphere, precipitation or seawater. EF was progressively applied to other environmental materials such as soils, lake sediments or peat [16]. It was also widely employed to identify the anthropogenic source of metallic elements [11]. EF values may fall into five different contamination categories as follows: 1) $\mathrm{EF}<2$ states deficiency to minimal enrichment; 2) $2 \leq \mathrm{EF}<5$ reflects moderate enrichment; 3 ) $5 \leq \mathrm{EF}<20$ shows significant enrichment; 4) $20 \leq \mathrm{EF} \leq 40$ represents very high enrichment, and; 5) $\mathrm{EF}>40$ is linked to extremely high enrichment [17]. EF value is calculated for the chemical elements using the following generalized equation $[18,19]$ :

$$
E F_{E l}=\frac{[E l]_{\text {sample }} /[X]_{\text {sample }}}{[E l]_{\text {crust }} /[X]_{\text {crust }}}
$$

where "El" is the element under consideration, the square brackets indicate concentration (usually in mass/mass units, such as $\mathrm{mg} / \mathrm{kg}$ ), " $\mathrm{X}$ " is the chosen reference element (see below) and the subscripts "sample" or "crust" indicate which medium the concentration refers to. Crust subscription in equation 1 refers to Clarke (the concentration of an element in a mineral or rock relative to its crustal abundance) of Earth's crust, most often Continental or Upper Continental Crust (UCC). The most common reference elements are Sc, $\mathrm{Mn}, \mathrm{Al}$ and $\mathrm{Fe}$ [20]. In this study, Scandinum was selected to be the reference value. Sc is undoubtedly the most common reference value used to calculate $\mathrm{EF}$ [21]. The reference element- scandium- rarely enter the atmospheric aerosols from anthropogenic sources.

\subsubsection{Contamination Factor (CF)}

The CF is contamination factor and is defined as the ratio of element 
concentration in a sample to its concentration in the background sample [21]. CF values higher than one indicate contamination:

$C F=\frac{C_{\text {Sample }}}{C_{\text {Background }}}$

where $\mathrm{C}_{\text {sample }}$ is the concentration of an element in the sample and $\mathrm{C}_{\text {background }}$ is the concentration of that element in the background sample. The background sample is obtained by statistical methods through comparing soil samples from the region with local soils not influenced by human factors $[22,23]$.

\subsubsection{Degree of contamination $\left(C_{d}\right)$}

Hakanson (1980) proposed an overall indicator of contamination based on integrating data for a series of seven heavy metals and the organic pollutant polychlorinated biphenyl (PCB). This method is based on the calculation for each pollutant of a contamination factor $\left(\mathrm{C}_{\mathrm{f}}\right) . \mathrm{C}_{\mathrm{f}}$ requires that at least five surficial soil samples are averaged to produce a mean pollutant concentration which is then compared to a baseline pristine reference level, according to the following equation:

$C_{f}=M_{X} / M_{b}$

where $M_{X}$ and $M_{b}$ respectively referring to the mean concentration of a pollutant in the contaminated soils and the pre-industrial "baseline" soils. The Hakanson's study also proposed that the numeric sum of the eight specific contamination factors expressed the overall degree of soil contamination $\left(\mathrm{C}_{\mathrm{d}}\right)$ using the following formula [24]:

$$
c_{d}=\sum_{i=1}^{5} c_{f}^{i}
$$

The calculated $\mathrm{C}_{\mathrm{d}}$ is therefore defined as the sum of the $\mathrm{C}_{\mathrm{f}}$ for five pollutant samples identified by Hakanson (1980). $C_{d}$ is aimed at providing a measure of the degree of overall contamination in surface layers in a particular sampling site. However, the Hakanson classification terminologies and calculation formula is based on and is restricted to the seven metals plus PCB specified in Hakanson's study. Furthermore, all five species must be analyzed in order to calculate the correct $C_{d}$ for the range of classes defined which makes this index more difficult to use.

\subsubsection{Modified degree of contamination $\left(m C_{d}\right)$}

As a result of limitations associated with calculating $C_{d}$, presented a modified and generalized equation for the calculation of the overall degree of contamination at a given sampling or coring site as follows [25]:

(1) The modified formula is generalized by defining the degree of contamination $\left(\mathrm{mC}_{\mathrm{d}}\right)$ as the sum of all the contamination factors $\left(\mathrm{C}_{\mathrm{f}}\right)$ for a given set of pollutants divided by the number of analyzing pollutants.

(2) The mean concentration of a pollutant element is based on the analysis of at least three samples of the impacted soils (taken from the associated surficial soils)

(3) The baseline concentrations are determined from lower core concentrations or from similar nearby uncontaminated soils.

The modified equation for a generalized approach to calculate the degree of contamination is given below:

$$
m c_{d}=\frac{\sum_{i=1}^{n} C f_{i}}{n}
$$

in which $n$ is equal to the number of analysed elements, $i$ is the $i^{\text {th }}$ element (or pollutant) and $\mathrm{C}_{\mathrm{f}}$ indicates contamination factor. Using this generalized formula to calculate the $\mathrm{mC}_{\mathrm{d}}$ allows the incorporation of as many metals as the study may require with no upper limits. The expanded range of possible pollutants can, thus, include both heavy metals and organic pollutants should the latter be available for the studied samples. For the classification and description of the modified degree of contamination $\left(\mathrm{mC}_{\mathrm{d}}\right)$ in estuarine soils the following gradations are proposed (Table 1).

Table 1: Classification and description of the modified degree of contamination $\left(\mathrm{mC}_{\mathrm{d}}\right)[25]$

\begin{tabular}{|c|c|}
\hline Value & Degree \\
\hline $\mathrm{mC}_{\mathrm{d}}<1.5$ & Nil to very low degree of contamination \\
\hline $1.5 \leq \mathrm{mC}_{\mathrm{d}}<2$ & Low degree of contamination \\
\hline $2 \leq \mathrm{mC}_{\mathrm{d}}<4$ & Moderate degree of contamination \\
\hline $4 \leq \mathrm{mC}_{\mathrm{d}}<8$ & High degree of contamination \\
\hline $8 \leq \mathrm{mC}_{\mathrm{d}}<16$ & Very high degree of contamination \\
\hline $16 \leq \mathrm{mC}_{\mathrm{d}}<32$ & Extremely high degree of contamination \\
\hline $\mathrm{mC}_{\mathrm{d} \geq 32}$ & Ultra high degree of contamination \\
\hline
\end{tabular}

An intrinsic feature of the $\mathrm{mC}_{\mathrm{d}}$ calculation is that it produces an overall average value for a range of pollutants. As with any averaging procedure, care must be taken in evaluating the final results from the effect of significant metal enrichment as spikes for individual samples may be hidden within the overall average result.

\subsubsection{Pollution Load Index (PLI)}

The pollution load index is a measure of the degree of overall contamination in a sample station [8]. The pollution load index is calculated using equation (5):

$$
P L I=\sqrt[n]{C F_{1} \times C F_{2} \times C F_{3} \times \ldots \times C F_{n}}
$$

PLI is capable of giving an estimate for the metal contamination status and the necessary action that should be taken. Pollution load index values higher than 1 indicate contamination and values close to one indicate similar concentrations of the contaminant in the studied sample and background sample $[23,26]$.

\subsubsection{Geo-accumulation Index (Igeo)}

The index of geo-accumulation enables the assessment of contamination by comparing the current levels of metal concentrations and the original pre-industrial concentrations in the soils. This index (also known as the Muller index) is used for risk assessment of metals in soils, which can be expressed as follows [27]:

$$
I_{\text {geo }}=\log _{2}(\mathrm{Cn} / 1.5 \mathrm{Bn})
$$

In this equation, $\mathrm{C}_{\mathrm{n}}$ is the measured concentration of the element in the sample and $B_{n}$ represents the concentration of the element in the background sample. The coefficient of 1.5 is used to minimize the effect of possible variations in the background values due to geological effects [28]. Seven classes (ranging from 0-6) of the geo-accumulation index was proposed by muller to classify the level of concentration of the soil or sediment by the metals. There are:

Class $0=I_{\text {geo }} \leq 0$ (practically uncontaminated)

Class $1=0<\mathrm{I}_{\text {geo }}<1$ (uncontaminated to moderately contaminated)

Class $2=1<$ Igeo $_{\text {g }}<2$ (moderately contaminated)

Class $3=2<\mathrm{I}_{\text {geo }}<3$ (moderately to heavily contaminated)

Class $4=3<\mathrm{I}_{\text {geo }}<4$ (heavily contaminated)

Class $5=4<$ Igeo $_{\text {ge }}<$ (heavily to extremely contaminated)

Class $6=5<$ Igeo $_{\text {go }}>6$ (extremely contaminated)

\subsection{Statistical analyses}

Multivariate and basic statistical analyses were applied to determine the relationship between heavy metals [29]. Application of multivariate statistical techniques facilitates interpretation of complex data matrices for a better understanding a variety of environmental factors [30]. Correlation analysis and principal component analysis (PCA) are performed using the commercial statistical software package SPSS version 
18.0 for Windows [31]. PCA was implemented to reduce the number of variables and to detect the relationship among different factors. This method allows us to display most of the original variability in a smaller number of dimensions and has been widely used in geochemical and hydrochemical studies [32].

In previous research a common method for comparing soil metal concentrations with precivilization background levels was to compare the present day metal levels with their concentrations in standard earth materials such as average shale or average crustal values [33-36]. Multivariate statistical methods are used in analytical chemistry to quantify relationships between more than two variables under simultaneous consideration of their interactions [37]. Heavy metals are famous to have complex relationships with each other [38]. The identification of pollutant sources is often determined with the aid of multivariate statistical analysis methods, such as correlation analysis and PCA.

In this work, the correlation coefficient between each pair of variable elements in the soil samples was calculated using the Pearson's correlation matrix approach to quantitatively analyze and confirm the relationship among various metal. The PCA method is widely used to reduce data and to extract a small number of latent factors for analyzing relationships among the observed variables. It has been reported that PCA methods have been widely used in geochemical applications to identify soil pollution sources and distinguish natural versus anthropogenic contribution [39].

\section{DISCUSSION}

\subsection{Statistical Analysis Methods}

\subsubsection{Descriptive basic statistics}

The statistical parameters including minimum, maximum and mean were calculated for the five heavy metals $\mathrm{Pb}, \mathrm{Ni}, \mathrm{Se}, \mathrm{Mo}$ and $\mathrm{Zn}$ (Table 2).

Table 2: Descriptive basic statistics of the metals in the surficial soils of the region under study $(\mathrm{mg} / \mathrm{kg})$

\begin{tabular}{|c|c|c|c|c|c|}
\hline Element & Valid N & Mean & Maximum & Minimum & Std. Dev. \\
\hline $\mathrm{Pb}$ & 60 & 124.2 & 1120 & 11.3 & 156.01 \\
\hline $\mathrm{Ni}$ & 60 & 25.2 & 87.00 & 7.1 & 36.8 \\
\hline $\mathrm{Se}$ & 60 & 1.66 & 4.20 & 0.2 & 2.01 \\
\hline $\mathrm{Mo}$ & 60 & 8.4 & 38.70 & 0.42 & 17.4 \\
\hline $\mathrm{Zn}$ & 60 & 246.2 & 2650.0 & 35.80 & 299.90 \\
\hline
\end{tabular}

The maximum concentration of the metals $\mathrm{Pb}, \mathrm{Ni}, \mathrm{Se}, \mathrm{Zn}$ and Mo are measured, and the results are $1120,87,4.2,2650$ and $38.7 \mathrm{mg} / \mathrm{kg}$, respectively. It is required to classify the elements according to the source and the rate of contamination, with using the statistical methods, PCA, the contamination coefficient.

\subsubsection{Multivariate Statistical Analyses}

Correlation and principal component analyses were performed using SPSS 21.0 Software [31].

\subsubsection{Correlation analysis}

As discussed previously, a Pearson's correlation matrix was used to assess element associations and metal origins. The results of the Pearson's correlation coefficients are shown in Table 3. The obtained results of correlation analysis indicate that:

The high positive correlation between the Mo and $\mathrm{Pb}$ metals is related to porphyry copper deposits and location of their alteration. Lead is a chalcophile metallic element. The natural $\mathrm{Pb}$ content in soil is, of course, related to the composition of the parent rock. Although the species of $\mathrm{Pb}$ vary considerably with soil type, it is mainly associated with clay minerals, $\mathrm{Mn}$ oxides, $\mathrm{Fe}$ and $\mathrm{Al}$ hydroxides and organic matter [40]. In addition, metalliferous mining (especially sulfide ores), is one potential source of $\mathrm{Pb}$. Molybdenum is a strongly chalcophile or siderophile metallic element forming several minerals.

$\mathrm{Pb}$ and $\mathrm{Zn}$ metals are concentrated in the marginal zones of porphyry copper and thus high content in the soil sampling stations is expected. Movability of $\mathrm{Zn}$ is known in the mining areas that shows a high significant correlation with Se. Zinc is a chalcophile metallic element and forms several minerals. $\mathrm{Zn}$ content in soil depends on the nature of parent rocks, texture, organic matter and $\mathrm{pH}$, and ranges from 10 to $300 \mathrm{mg} \mathrm{kg}^{-1}$ with an estimated global average of $64 \mathrm{mg} \mathrm{kg}^{-1}$ [40, 41]. Zinc mobility in the environment is greatest under oxidizing, acidic conditions and more restricted under reducing conditions. Weathering of sulfide minerals in oxidizing conditions may give rise to high concentrations $\left(>100 \mu \mathrm{g} \mathrm{l}^{-1}\right)$ of dissolved Zn sulfates and carbonates [42]. Selenium is a chalcophile nonmetallic element forming several rare minerals, but is more widely present as an accessory element replacing sulphur in more common sulfide minerals, such as pyrite, chalcopyrite, pyrhotite and sphalerite. During volcanic activity, Se escapes with high temperature volcanic gases and its concentrations in volcanic rocks are, therefore, generally low. Selenium is highly mobile under oxidizing, acidic, neutral and alkaline conditions, although its mobility decreases with decreasing $\mathrm{pH}$, and it is immobile under reducing conditions [43].

Table 3: Pearson's correlation matrix showing the inter-elemental relationship $(n=60)$

\begin{tabular}{|c|c|c|c|c|c|}
\hline Element & $\mathrm{Pb}$ & $\mathrm{Zn}$ & $\mathrm{Mo}$ & $\mathrm{Se}$ & $\mathrm{Ni}$ \\
\hline $\mathrm{Pb}$ & 1 & & & & \\
\hline $\mathrm{Zn}$ & $\mathbf{0 . 8 5}$ & 1 & & & \\
\hline $\mathrm{Mo}$ & $\mathbf{0 . 7 0 1}$ & 0.303 & 1 & & \\
\hline $\mathrm{Se}$ & 0.562 & $\mathbf{0 . 6 1 8}$ & 0.532 & 1 & \\
\hline $\mathrm{Ni}$ & 0.209 & 0.312 & 0.294 & 0.082 & 1 \\
\hline
\end{tabular}

\subsubsection{Principal component analysis (PCA)}

PCA is a linear combination of variables. For factor loadings, a high loading was defined as greater than 0.75 , and a moderate loading was defined as 0.40-0.75. Loadings of less than 0.40 were considered insignificant [44]. PCA and varimax rotation in order to determine the optimum number of factors have been performed using SPSS software (version 21). Two significant components were retained based on the eigenvalues of greater than one [45]. The results of applying PCAfor metal concentrations in Meiduk copper mine area soils are reported in Table 4. According to the results of the initial eigenvalues, the two principal components were considered, which account for over $86 \%$ of the total variance. Principal component analysis for different metals (Table 4) is presented as follows:

In the first component (PC1), with $51 \%$ of the total variance, shows strong and positive loadings related to $\mathrm{Pb}, \mathrm{Se}, \mathrm{Mo}$ and $\mathrm{Zn}$. Correlation coefficient and PCA analysis results indicated a strong correlation between metals ( $\mathrm{Mo}, \mathrm{Pb} ; \mathrm{Pb}, \mathrm{Zn} ; \mathrm{Zn}, \mathrm{Se}$ ). Base metal mining is also a significant source of anthropogenic contamination. Anthropogenic sources of zinc are significant, arising mainly from industrial activities such as mining. Molybdenum is also released into the environment from the dispersion of mine waste. Lead $(\mathrm{Pb})$, a non-essential and toxic element, is released from natural and anthropogenic activities (use of fertilizers and pesticides). In high concentrations, selenium acts as an environmental contaminant.

Sources of pollution include waste materials from certain mining, agricultural, petrochemical, and industrial manufacturing operations. The second component (PC2), with $34 \%$ of the total variance, a positive weighting factor of Ni metal. Nickel is a siderophile metallic element with chocoholic and lithophilic affinities and forms several minerals. It is also present in appreciable amounts in common sulfide minerals, such as pyrite and chalcopyrite, and often correlates well with $\mathrm{Cu}$ in sulfide-rich rocks [46]. Nickel is highly mobile under acidic, oxidizing conditions. In the presence of some organic complexing agents, $\mathrm{Ni}$ is capable of forming neutral or negatively charged complexes, making the metal highly mobile in relation to other trace elements. 
Table 4: Total variance explained and rotated factor pattern of two factors after varimax rotation in the study area

\begin{tabular}{|c|c|c|}
\hline Element & Component 1 & Component 2 \\
\hline $\mathbf{P b}$ & $\mathbf{0 . 9 1 7}$ & 0.234 \\
\hline $\mathbf{N i}$ & 0.101 & $\mathbf{0 . 8 2 0}$ \\
\hline Se & $\mathbf{0 . 8 0 5}$ & -0.321 \\
\hline Mo & $\mathbf{0 . 7 2 5}$ & -0.569 \\
\hline Zn & $\mathbf{0 . 8 1 0}$ & 0.402 \\
\hline \% of Variance & 51.521 & 34.479 \\
\hline Cumulative Variance (\%) & 51.521 & 86.061 \\
\hline
\end{tabular}

Extraction method: principal component analysis

Rotation method: varimax with Kaiser normalization

\subsection{Environmental assessment of heavy metals contamination}

To determine the extent of contamination with heavy metals the elements of a studied area is compared with thresholds defined by the World Health Organization (WHO). Calculated environmental pollution indices are listed in Table 5 and Table 6 . Table 5 is showing modified degree of contamination and contamination factors for heavy metals in soil samples of the study area based on average continental crust and background values. Table 6 illustrates the calculated values for metals in the soils and the associated pollution load to the region [47]. EF values are presented in Table 6. Lead, zinc and molybdenum show high EF in the soil samples indicating that there is a considerable heavy metal pollution, which could be correlated with the mining activities in the area. The calculated PLI in this study was 2.1.

Table 5: Modified degree of contamination $\left(\mathrm{mC}_{\mathrm{d}}\right)$ and contamination factors (CF) for heavy metals in soil samples of the study area

\begin{tabular}{|c|c|c|c|c|c|c|c|}
\hline \multirow[t]{2}{*}{ Baseline } & \multicolumn{5}{|c|}{ Contamination Factor } & \multirow[t]{2}{*}{ Sum CF } & \multirow[t]{2}{*}{$m c_{d}$} \\
\hline & $\mathrm{Se}$ & $\mathrm{Zn}$ & $\mathrm{Ni}$ & Mo & $\mathrm{Pb}$ & & \\
\hline $\begin{array}{c}\text { CF (Average } \\
\text { continental crust) }\end{array}$ & 2.64 & 4.01 & 1.42 & 3.87 & 3.92 & 15.86 & 3.17 \\
\hline CF (Background) & 0.88 & 3.62 & 1.83 & 4.45 & 3.72 & 14.5 & 2.90 \\
\hline \multicolumn{8}{|l|}{ Concentration $(\mathrm{mg} / \mathrm{kg})$} \\
\hline $\begin{array}{l}\text { Average continental } \\
\text { crust }\end{array}$ & 0.4 & 65 & 40 & 2 & 14.8 & * & * \\
\hline Background & 1.1 & 66 & 15 & 1.03 & 31 & * & * \\
\hline
\end{tabular}

Igeo $_{\text {ge }}$ classes were calculated for each sampling station. Results of Geoaccumulation index calculations show that the environment and contamination levels are from non- contaminated (Se and $\mathrm{Ni}, \mathrm{I}_{\text {geo }}<0$, natural origins) to low contamination ( $\mathrm{Zn}, \mathrm{Mo}$ and $\mathrm{Pb}, \mathrm{I}_{\text {geo }}>0$, anthropogenic sources). Further, the analysis of modified degree of contamination $\left(\mathrm{mC}_{\mathrm{d}}\right)$ indicates $\mathrm{Nil}$ to the very low degree of contamination (Table 5).

Table 6: Calculation results of the risk indicators for heavy metals in soils of the study area

\begin{tabular}{|c|c|c|c|c|c|c|}
\hline Element & WHO value & $\mathrm{CF}$ & $\mathrm{EF}$ & $\begin{array}{c}\text { Classification of } \\
\text { concentration factor }\end{array}$ & $\mathrm{I}_{\mathrm{geo}}$ & $\begin{array}{l}\text { Intense pollution of the area } \\
\text { on the basis of Igeo }\end{array}$ \\
\hline Se & 10 & 0.88 & 1.43 & No concentration & $<0$ & No contamination \\
\hline Zn & 300 & 3.62 & 2.75 & $\begin{array}{l}\text { Medium (avg.) } \\
\text { concentration }\end{array}$ & 0.35 & $\begin{array}{l}\text { Uncontamination- } \\
\text { Low contamination }\end{array}$ \\
\hline $\mathrm{Ni}$ & 80 & 1.83 & 0.62 & Low concentration & $<0$ & No contamination \\
\hline Mo & 70 & 4.45 & 2.15 & High concentration & 0.19 & $\begin{array}{l}\text { Uncontamination- } \\
\text { Low contamination }\end{array}$ \\
\hline $\mathrm{Pb}$ & 100 & 3.72 & 6.67 & $\begin{array}{l}\text { Medium (avg.) } \\
\text { concentration }\end{array}$ & 1.32 & Low contamination \\
\hline
\end{tabular}

Results from the calculation of the geo-accumulation index can explain that the Nickel and Selenium elements are lying with uncontaminated area and zinc and molybdenum are lying with uncontaminated area and up to the low contaminated area and lead element is lying in the area of lower contamination.

\subsection{Background values from average crustal concentrations}

Figure 3 presents a comparison of the mean concentrations of potentially toxic metals in samples with the average crust values for noncontaminated soils. Also, based on average shale values, higher levels of contaminated metals are $\mathrm{Pb}, \mathrm{Se}, \mathrm{Mo}$ and $\mathrm{Zn}$ compared to the average crust values. Nickel are less than the average shale.

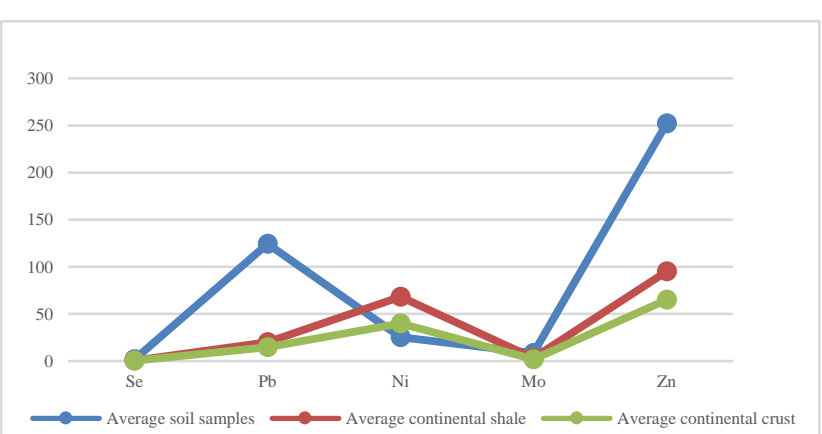

Figure 3: A comparison of the mean concentrations of potentially toxic metals in soil samples of the region under study with the average crust values for uncontaminated soils and average shale

\subsection{Spatial distribution of heavy metals}

A soil pollution assessment becomes very complex when different sources of contamination are present and their products are variably distributed. In these cases, the spatial variability of heavy metal concentrations in soils is basic information for identifying the possible sources of contamination and to delineate the strategies of site remediation [8]. In this research, spatial distribution map of heavy metals $(\mathrm{Pb}, \mathrm{Ni}, \mathrm{Se}, \mathrm{Mo}$ and $\mathrm{Zn})$ using the ordinary inverse distance weighting (IDW) method is created in the study area based on raw samples. Figures 4, 5, 6, 7 and 8 illustrate the spatial distribution of different metals as discussed in the following sections.

\subsubsection{Lead $(\mathrm{Pb})$ metal}

The common use of lead makes its concentration in all environmental media elevated. Lead, a non-essential and toxic element, is released from natural and anthropogenic activities. Major sources include vehicular emissions, volcanoes, airborne soil particles, forest fires, waste incineration, effluents from leather industry, lead containing paints and pesticides [48-50]. The natural concentration of $\mathrm{Pb}$ in the earth's crust varies from 15 to $20 \mathrm{mg} / \mathrm{kg}$ [48]. Results show that $\mathrm{Pb}$ concentrations $(\mathrm{mg} / \mathrm{kg})$ in the soils ranged from 11.3 to 1120.0 . The comparison between $\mathrm{Pb}$ concentrations in the soils of the study area show that $\mathrm{Pb}$ levels in the near mine pit (anthropogenic source) and northwest parts (geogenic source) had higher levels than other measured stations in the study area (Figure 4). Therefore, among heavy metals, $\mathrm{Pb}$ is the immobile element and its content in soil is closely associated with clay minerals, Mn-oxides, $\mathrm{Al}$ and Fe hydroxides, and organic material. Considering the health hazards from the accumulation of heavy metals, especially the high level of lead in this study, it is quite needed to properly monitor mining sites and areas. 


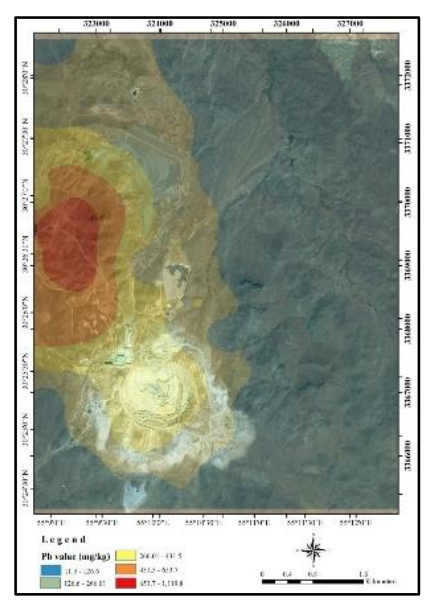

Figure 4: Spatial distribution map of $\mathrm{Pb}$ metal

\subsubsection{Zinc (Zn)}

Natural background levels of zinc are usually found up to $100 \mathrm{mg} / \mathrm{kg}$ in soils [51]. Sources of $\mathrm{Zn}$ are natural processes and human activities. The concentrations $(\mathrm{mg} / \mathrm{kg})$ of $\mathrm{Zn}$ in the study area ranged from 35.80 to 2650.0 (Figure 5). High concentrations of $\mathrm{Pb}$ and $\mathrm{Zn}$ reflect the main components of the minerals extracted from the mine sites, such as galena $(\mathrm{PbS})$ and sphalerite $(\mathrm{ZnS})$.

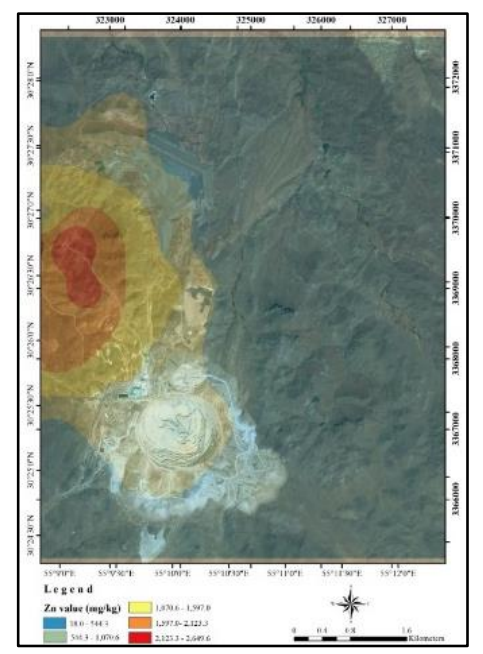

Figure 5: Spatial distribution map of Zn metal

\subsubsection{Molybdenum (Mo)}

The average Molybdenum content in the tested soils was $8.40 \mathrm{mg} / \mathrm{kg}$ ranging from 2.3 to $15.60 \mathrm{mg} / \mathrm{kg}$. Mo concentrations $(\mathrm{mg} / \mathrm{kg})$ ranged between 0.42 to 38.70 in the study area (Figure 6).

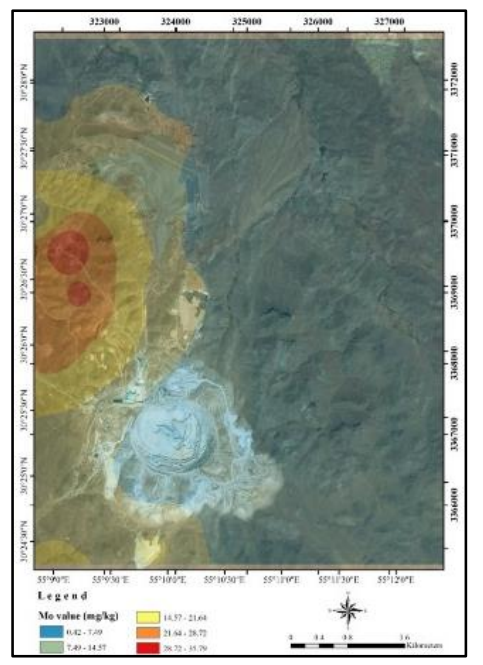

Figure 6: Spatial distribution map of Mo metal

\subsubsection{Selenium (Se)}

Se is released into the environment from natural sources such as volcanic eruptions, decaying vegetation, forest fires, and sea spray etc. up to 50 $\mathrm{mg} / \mathrm{kg}$ and anthropogenic activities, including municipal and industrial wastewater [49,52-54]. The results show that Se concentrations $(\mathrm{mg} / \mathrm{kg})$ in the soils of the study area ranged from 0.2 to 4.20 . The comparison between Se concentrations in the soil of the study area show that Se levels are below the natural maximum values in the study area (Figure 7).

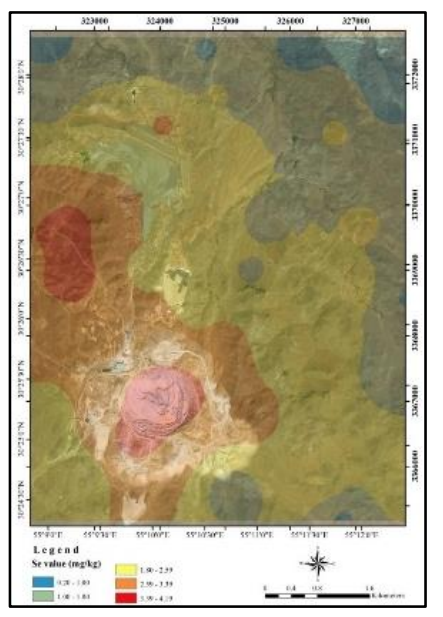

Figure 7: Spatial distribution map of Se metal

\subsubsection{Nickel (Ni)}

Nickel is a transition element that occurs in the environment only at very low levels. It occurs mostly in minerals such as pentlandite, garnierite, millerite, niccolite and ulmannite. Nickel is commonly present in two principal ore types: sulphide or laterite. Nickel content in soils varied widely and have been estimated to range from 3 to $1000 \mathrm{mg} / \mathrm{kg}$; for the world soils, the brand range is between 0.2 and $450 \mathrm{mg} / \mathrm{kg}$, while the grand mean is calculated to be $22 \mathrm{mg} / \mathrm{kg}[55,56]$. Some researchers also reported an average concentration of $86 \mathrm{mg} / \mathrm{kg}$ for the natural nickel content in the earth's crust. Major sources of nickel contamination in soil are metal plating industries, combustion of fossil fuels, and nickel mining and electroplating $[57,58]$.

The results show that Ni concentrations $(\mathrm{mg} / \mathrm{kg}$ ) in the soils ranged from 7.1 to 87.00. The comparison between Ni concentrations in the soils of the study area show that $\mathrm{Ni}$ levels in the northwest parts had higher levels than other measured stations of the study area (Figure 8). The spatial distribution of the metals in the soils is not uniform over the entire section of the study area. Changes in concentration are pertinent to the magnitude and temporal and spatial extension of release of heavy metals from different natural and anthropogenic sources. Heavy metals concentration levels and distribution were found higher at the sites located in the vicinity of mine pits and waste dumps that are probable sources of metal pollution.

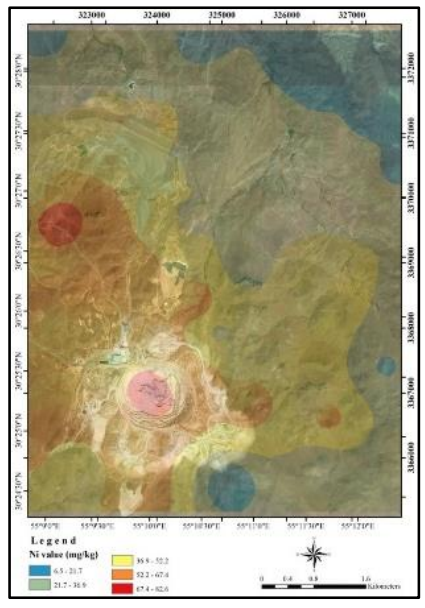

Figure 8: Spatial distribution map of Ni metal 
The highest levels of $\mathrm{Pb}, \mathrm{Zn}$, and Mo were found in the soil from mine site and other small ore deposits. The concentration levels of heavy of metals ( $\mathrm{Ni}$, and $\mathrm{Se}$ ) in the soil were generally low and found to be within the World Health Organization (WHO) permissible levels. The variations of $\mathrm{Mo}, \mathrm{Pb}$, and $\mathrm{Zn}$ demonstrated a very similar pattern, with the most heavily contaminated areas appearing in the mining waste dump area and in the vicinity of the ore deposits. In order to minimize environmental issues associated with mining activities in the Meiduk region suggest to enhance the management of mining activities by focusing on the tailings management, especially at the mine sites with critical downstream contamination

\section{CONCLUSION}

In this study, the pollution indices, including the contamination factor $(\mathrm{CF})$, Average concentration, the enrichment factor (EF) and geoaccumulation index ( $\mathrm{I}_{\mathrm{geo}}$ ) were used to evaluate of metal pollution from $\mathrm{Pb}$, $\mathrm{Ni}, \mathrm{Se}, \mathrm{Mo}$ and $\mathrm{Zn}$ in soils around of the Meiduk mine area. The average of $\mathrm{Pb}, \mathrm{Ni}, \mathrm{Se}, \mathrm{Mo}$ and $\mathrm{Zn}$ metals shows a higher quantity with respect to the world average quantity. The calculation of the corrected pollutant degree indicates the degree of the bulk intermediate pollutant (2.90-3.17) for the average soil sampling of the study area which is on the basis of the background quantity and the world average quantity of the uncontaminated soils. Calculation of concentrated factor indicated that for 20 stations the average of the lead, zinc and molybdenum in the study area is more than the background values and the unnatural metals concentration was covered under the study area. The distribution of heavy metals in the soil was not uniform over the whole section of the study area and the change in concentration was due to the release of these metals from different natural and anthropogenic sources. Heavy metals levels and distribution was found higher at that sites which were in the vicinity of mine pits and waste dumps and were probable sources of metal pollution. In this research, we applied principal component analysis of compositional data. In the first component (PC1), with 51\% of the total variance, shows strong and positive loadings related to $\mathrm{Pb}, \mathrm{Se}, \mathrm{Mo}$ and $\mathrm{Zn}$ metals. The second component (PC2), with $34 \%$ of the total variance, a positive weighting factor of $\mathrm{Ni}$ metal. Based on the results from the present study, it can be concluded that mining activities contribute to elevated level of heavy metals in surrounding soils of the mining areas. Therefore, heavy metals contaminant, in the Meiduk area should be carefully monitored and controlled in the future.

\section{ACKNOWLEDGEMENTS}

The authors would like to thank the Amirkabir University of Technology (Polytechnic Tehran) for supporting this research. The contribution of Samira Rezaei is appreciated. The authors would like to thank the reviewers for their very helpful and constructive reviews of this manuscript.

\section{REFERENCES}

[1] Taylor, K.G., Owens, P.N. 2009. Sediments in urban river basins: a review of sediment- contaminant dynamics in an environmental system conditioned by human activities. Journal of Soils and Sediments, 9, 281303.

[2] Meza-Figueroa, D., Maier, R.M., De la O-Villanueva, M., Gómez-Alvarez, A., Moreno-Zazueta, A., Rivera, J. 2009. The impact of unconfined mine tailings in residential areas from a mining town in a semi-arid environment: Nacozari, Sonora, Mexico. Chemosphere, 77, 140-147.

[3] Qiao, M., Cai, C., Huang, Y., Liu, Y., Lin, A., Zheng, Y. 2011. Characterization of soil heavy metal contamination and potential health risk in metropolitan region of northern China. Environmental Monitoring and Assessment, 172 (1), 353-365.

[4] Tsafe, A.L., Hassan, L.G., Sahabi, D.M., Alhassan, Y., Bala, B.M. 2012. Evaluation of heavy metals uptake and risk assessment of vegetables grown in Yarglama of northern Nigeria. J. Basic and Applied Scientific Res., 27, 66-71.

[5] Reyes, A., Thiombane, M., Panico, A., Daniele, L., Lima, A., Di Bonito, M., De Vivo, B. 2019. Source patterns of potentially toxic elements (PTEs) and mining activity contamination level in soils of Taltal city (northern Chile). Environ Geochem Health, https://doi.org/10.1007/s10653-019-004045(0123456789().,-volV

[6] Ettler, V. 2016. Soil contamination near non-ferrous metal smelters: A review. Applied Geochemistry, 64, 56-74.

[7] Rodriguez, L., Ruiz, E., Alonso-Azcarate, J., Rinconb, J. 2009. Heavy metal distribution and chemical speciation in tailings and soils around a $\mathrm{Pb}-\mathrm{Zn}$ mine in Spain. J. Environ. Manage., 90 (2), 1106.

[8] Rezaei, A., Hassani, H., Fard mousavi, S.B., Jabbari, N. 2019. Evaluation of heavy metals concentration in jajarm bauxite deposit in northeast of iran using environmental pollution indices. Malaysian Journal of Geosciences (MJG), 3, 12-20.

[9] Pérez-López, M., de Mendoza, M.H., Beceiro, A.L., Rodríguez, F.S. 2008. Heavy metal $(\mathrm{Cd}, \mathrm{Pb}, \mathrm{Zn})$ and metalloid (As) content in raptor species from Galicia (NW Spain). Ecotoxicology and environmental safety, 70, 154-162.

[10] Gallagher, F.J., Pechmann, Bogden, J.D., Grabosky, J., Weis, P. 2008. Soil metal concentrations and vegetative assemblage structure in an urban brownfield. Environmental Pollution, 153, 351-361.

[11] Li, X., Feng, L. 2012. Multivariate and geostatistical analyzes of metals in urban soil of Weinan industrial areas. Northwest of China, Atmospheric Environ, 47, 58-65.

[12] Hezarkhani, A. 2008. Hydrothermal Evolution of the Miduk Porphyry Copper System, Kerman, Iran: A Fluid Inclusion Investigation. International Geology Review, 50, 7.

\section{[13] WWW.LABWEST.NET}

[14] Rezaei, A., Rahimi Pour, G.H., Amin Shirazi, H.H. 2009. Sampling optimization to reduce plant feed grade variation at miduk copper complex. Thesis of M.Sc., 158.

[15] Govil, P., Reddy, G., Krishna, A. 2001. Contamination of soil due to heavy metals in the Patancher industrial development area, Andhra Pradesh, India. Environmental Geology., 41, 461- 469.

[16] Bourennane, H., Douay, F., Sterckeman, T., Villanneau, E., Ciesielski, H., King, D., Baize, D. 2010. Mapping of anthropogenic trace elements inputs in agricultural topsoil from Northern France using enrichment factors. Geoderma., 157, 165-174.

[17] Han, Y., Du, P., Cao, J., Posmentier, E.S. 2006. Multivariate analysis of heavy metal contamination in urban dusts of Xi'an, Central China. Sci Total Environ., 355, 176-186.

[18] Chester, R., Stoner, J.H. 1973. Pb in particulates from the lower atmosphere of the eastern Atlantic. Nature, 245, 27-28.

[19] Zoller, W.H., Gladney, E.S., Duce, R.A. 1974. Atmospheric concentrations and sources of trace metals at the South Pole. Science, 183, 199-201.

[20] Loska, K., Cebula, J., Pelczar, J., Wiechuła, D., Kwapuliński, J. 1997. Use of enrichment, and contamination factors together with geoaccumulation indexes to evaluate the content of $\mathrm{Cd}, \mathrm{Cu}$, and $\mathrm{Ni}$ in the Rybnik Water Reservoir in Poland. Water, Air, Soil Pollut., 93, 347.

[21] Hayaty, M., Tavakoli Mohammadi, M.R., Rezaei, A., Shayestehfar, M.R. 2014. Risk Assessment and Ranking of metals Using FDAHP and TOPSIS. Mine Water Environ., 33, 2, 157-164.

[22] Abrahim, G.M.S., Parker, R.J. 2008. Assessment of heavy metal enrichment factors and the degree contamination in marine sediments from Tamaki. Estuary, Auckland, New Zealand. Environmental Monitoring and Assessment, 136, 227- 238

[23] Adomako, D., Nyarko, B.J.B., Dampare, S.B., Serfor- Armah, Y., Osae, S., Fianko, J.R., Akaho, E.H. 2008. Determination of toxic elements in waters and sediments from River Subin in the Ashanti Region of Ghana. Environ Monit Assess., 141, 165- 175.

[24] Hakanson, L. 1980. Ecological Risk Index for Aquatic Pollution Control, a Sedimentological Approach. Water Research, 14, 975-1001. 
[25] Saet, Y.E., Revich, B.A., Yanin, E.P. 1988. Geochemistry of the Environment, Nedra, Moscow.

[26] Qishlag, A., Moore, F., Forghani, G. 2007. Impact of untreated wastewater irrigation on soils and crops in Shiraz suburban area, SW Iran. Environmental Monitiring Assessment, 149, 254- 262.

[27] Audry, S., Schafer, J., Blanc, G., Jouanneau, J.M. 2004. Fifty- year sedimentary record of heavy metal pollution $(\mathrm{Cd}, \mathrm{Zn}, \mathrm{Cu}, \mathrm{Pb})$ in the Lot River reservoirs (France). Environmental Pollution, 132 (3), 413- 426.

[28] Chen, C.W., Kao, C.M., Chen, C.F., Dong, C.D. 2007. Distribution and accumulation of heavy metals in the sediments of Kaohsiung Harbor, Taiwan. Chemosphere, 66 (8), 1431- 1440.

[29] Yinxian, S., Junfeng, J., Zhongfang, Y., Xuyin, Y., Changping, M., Ray, F., Godwin, A. 2011. Geochemical behavior assessment and apportionment of heavy metal contaminants in the bottom sediments of lower reach of Changjiang River. Catena, 85, 73-81.

[30] Rezaei, A., Hassani, H., Jabbari, N. 2017. Evaluation of Groundwater Quality and Assessment of Pollution Indices for heavy metals in North of Isfahan Province, Iran. J Sustainability Water Resource Management.

[31] Statistical Package for the Social Sciences (SPSS) Inc SPSS 21. 2017. http://www.spss.en.softonic.com

[32] Razo, I., Carrizales, L., Castro, J., D’1az-Barringa, F., Monroy, M. 2004. Arsenic and heavy metal pollution of soil, water and sediments in a semiarid climate mining area in Mexico. Water Air Soil Pollu, 152, 129-152.

[33] Salomons, W., Fortner, U. 1980. Metals in the hydrocycle. Berlin Heidelberg Tokyo.

[34] Mapanda, F., Mangwayana, E., Nyamangara, J., Giller, K. 2007. Uptake of heavy metals by vegetables irrigated using wastewater and the subsequent risks in Harare, Zimbabwe. Physics and Chemistry of the Earth, Parts A/B/C, 32, 1399- 1405.

[35] Turekian, K.K., Wedepohl, D.H. 1961. Distribution of the elements in some major units of the earth's crust. Bulletin Geological Society of America, 72, 175-192.

[36] Taylor, S.R. 1964. The abundance of chemical elements in the continental crust - A new table. Geochimica Cosmochimica Acta, 28, 12731285 .

[37] Krzanowski, W.J. 1988. Principles of Multivariate Analysis, Clarendon Press.

[38] Sun, Y., Zhou, Q., Xie, X., Liu, R. 2010. Spatial, sources and risk assessment of heavy metal contamination of urban soils in typical regions of Shenyang, China. Journal of Hazardous Materials, 174, 455-462.

[39] Rezaei, A., Hassani, H., Hassani, S., Jabbari, N., Fard Mousavi, S.B., Rezaei, S. 2019. Evaluation of groundwater quality and heavy metal pollution indices in Bazman basin, southeastern Iran. Journal of Groundwater for Sustainable Development, 9, https://doi.org/10.1016/j.gsd.2019.100245.

[40] Kabata-Pendias, A., Mukherjee, A.B. 2007. Trace elements from soil to human, (Springer Berlin Heidelberg New York.

[41] Mihaljevic, M., Marshall, C.P., and Fairbridge, R.W. 1999. Zinc Encyclopedia of Geochemistry. Kluwer Academic Publisher, Dordrecht, Germany, 674-675.
[42] Massey, H.F., Barnhisel, R.I. 1972.Copper, nickel, and zinc released from acid coal mine spoil materials of eastern Kentucky. Soil Sci, 3, 113.

[43] Gondi, F., Panto, G., Feher, J., Bogye, G., Alfthan, G. 1992. Selenium in Hungary. The rock- soil-human system, Biol Trace Elem Res., 35, 299- 306.

[44] Evans, C.D., Davies, T.D., Wigington, P.J., Tranter, M., Kretser, W.A. 1996. Use of factor analysis to investigate processes controlling the chemical composition of four streams in Adirondack Mountains, New York. Journal of Hydrol., 185, 297- 316.

[45] Kaiser, H.F. 1958. The varimax criterion for analytic rotation in factor analysis. Psychometrika, 23, 187-200.

[46] Wedepohl, K.H. 1978. Handbook of Geochemistry, Springer Verlag, Berlin.

[47] Gonzales-Macias, C., Schifter, I., Liuch-Cota, D.B., Hendez-Rodriguez, L., Hernandez-Vazquez, S. 2006. Distribution, enrichment and accumulation of heavy metals in coastal sediments of Salina Cruz Bay, Mexico. Environmental Monitioring and Assessment, 118, 211- 230.

[48] Agency for Toxic Substance and Disease Registry (ATSDR). 2007. Toxicological profile for lead. Available at http://www.atsdr.cdc.gov/toxpro files/tp13.pdf.

[49] Ullah, K., Hashmi, M.Z., Malik, R.N. 2013. Heavy-metal levels in feathers of cattle egret and their surrounding environment: a case of the Punjab province, Pakistan. Arch. Environ. Contam. Toxicol., 66 (1), 139 153.

[50] Abdullah, M., Fasola, M., Muhammad, A., Malik, S.A., Boston, N., Bokhari, H., Kamran, M.A., Shafqat, M.N., Alamdar, , Khan, M., Ali, N., Eqani, S.A.M.A.S. 2015. Avian feathers as a non-destructive bio-monitoring tool of trace metals signatures: a case study from severely contaminated areas. Chemosphere, 119, $553-561$.

[51] World Health Organization. 2011. Environmental Health Criteria 221 Zinc. World Health Organization, Geneva, Switzerland.

[52] Agency for Toxic Substance and Disease Registry (ATSDR), 2004a. Toxicological profile for copper. Available at: http://www.atsdr.cdc.gov/toxpro files/tp132.pdf

[53] Agency for Toxic Substance and Disease Registry (ATSDR). 2004b. Toxicological profile for cobalt. Available at: http://www.atsdr.cdc.gov/toxpro files/tp33.pdf

[54] Saleem, M., Iqbal, J., Shah, M.H. 2013. Study of seasonal variations and risk assessment of selected metals in sediments from Mangla Lake, Pakistan. J. Geochem. Explor., 125, 144-152.

[55] Kabata- Pendias, A., Pendias, H. 1992. Trace elements in soils and plants. CRC Press, London.

[56] Cempel, M., Nikel, G. 2006. Nickel: A review of its sources and Environmental Toxicology. Polish J. of Environ. Stud., 15, 3, 375- 382.

[57] Duke, J.M. 1980. Production and uses of Nickel, Nickel in the Environment, John Wiley \& Sons, New York, 51-65.

[58] Khodadoust, A.P., Reddy, K.R., Matari, K. 2004. Removal of nickel and phenanthrene from kaolin soil using different extractants. Environment Engineering Science, 21 (6), 691- 704 